\title{
I Am an Ex-Service Man: Towards Defending Nigerian English Pragma-Lexico-Semantic Corpora
}

\author{
Acheoah John Emike (Ph.D) ${ }^{1}$ \\ Department of Language and Communication Studies, \\ Faculty of Arts, Management and Social Science, \\ Federal University, Dutsin-ma, Katsina State, Nigeria.
}

\begin{abstract}
Nigerian English discourse is not recent. In different fields of language study (phonology, morphology, semantics, pragmatics, etc.), scholars establish critical positions on the status of Nigerian English amidst world Englishes. Hinging basically on Lawal's Communicative Model Theory, this study makes a discursive, interdisciplinary discussion of what Nigerian English parades as her pragmatic, lexical and semantic data. Scholars express the need for extensive research on how discourse operates in the usage of English in non-native regions. Defending Nigerian English, this study concludes that in Nigeria, discourse is not merely a mechanical process as it also involves creativity on the part of Nigerian speakers of English. Howbeit, Nigerians "nativize" English by using it beyond its formal properties to produce what the study labels the "pragma-lexico-semantic corpora" of Nigerian English.
\end{abstract}

Keywords: Nigerian English, pragmatics, semantics, sociolinguistics, Geoimplicature.

\section{INTRODUCTION}

"In the mindset of many Nigerians, an "ex-teacher" means a "retired teacher", but an "ex-serviceman" does not mean a "retired service man", but a "retired soldier".

(Acheoah, John Emike 2015 - forthcoming)

“...In other words, Nigeria awaits its Noah Webster."

(Banjo, 1982:4)

The study is not a textual analysis. It is an integrative, discursive presentation of samples of expressions used in Nigeria. The study presents English as a product of colonialism which Nigeria experienced during the British rule in the country ${ }^{1}$. The focus of the study makes it a research into different, but related areas of language study: sociolinguistics, pragmatics and semantics. Issues examined in this study border on how people within a region encode and decode utterances. The English Language is not native to Nigerians, yet it is the lingua franca of their country. Britain, for close to 200 years, colonized Nigeria, and because English was the language of the British colonialists, they introduced it through various sources: religion, commerce, education, general administration, mass media, etc. (Ayodabo 2012). See Akindele and Adegbite (1999) for more insights on Nigerian English (NE). It is worrisome that Nigerian English, like other "nativized Englishes", is labeled variously: "taboo", "non-standard English", "ethnic stigmatizations" and "language choices informed by incompetence in the formal properties of English". Dislodging the pre-established ugly qualities ascribed to Nigerian English, this study argues that it is "social competence" rather than "linguistic incompetence", which generates regional Englishes, including Nigerian English.

\section{LANGUAGE AND CONTEXT}

In this section, I briefly discuss language, meaning, context and situation through a review of pragmatics, sociolinguistics and semantics.

\subsection{Pragmatics}

The Encyclopedia Americana (1994 Vol.22:514) defines pragmatics as "the subfield of the study of language that investigates the techniques by which language is processed for communication purposes." The pragmatic analysis of language can be broadly understood to be the investigation into that aspect of meaning which is derived not from the

\footnotetext{
${ }^{1}$ Corresponding Author: actualemike@gmail.com
} 
formal properties of words and constructions, but from the way in which utterances are used and how they relate to the context in which they are uttered. Adegbija (1999) states that the scope of pragmatics includes: the message being communicated, the participants involved in the message, the knowledge of the world which they share, the deductions to be made from the text on the basis of the context and the impact of the non-verbal aspect of interaction on meaning.

\subsection{Sociolinguistics}

Sociolinguistics is the study of language and society. In this regard, various social variables which produce and interpret Nigerian English are of sociolinguistic interest. This paper subtly underscores cross-cultural pragmatics by discussing how the Nigerian socio-cultural realities affect the use of English in Nigeria. By bringing the notion, "Geoimplicature" (cf. Acheoah 2011) into this study, the paper attempts to explain and justify the communicative patterns of Nigerians. The study of language use in societies, termed "sociolinguistics", focuses on the relationship between linguistic behaviours as well as social situations and functions ${ }^{2}$. This is typical of both written and spoken discourses. The study views linguistic behaviours from the perspective of Geoimplicatures. Lucas (2002:33) observes that "communication depicts a process by which meanings (often times abstract or subtle)) are exchanged among individuals, groups or organizations through a system of mutually shared words, signs and symbols." Scholars acknowledge that Social Identity Theory recognizes the fact that social stereotypes (the process of ascribing characteristics to individuals based on group membership) help people to systematize their world since more importantly, when people affirm their stereotypes, such features become identities". Geoimplcatures are "Nigerianisms" in the use of English. Acheoah (ibid.) coins the term, "Geoimplicature" from "geographical" and "implicature" to refer to "practices that have geographical restrictions in terms of people" (Nigerians epitomize Nigerian values within and outside Nigeria). Such values or practices which are either verbal or non-verbal are not necessarily universal.

\subsection{Semantics}

Language cannot have communicative potentials if the utterances it employs are not message-laden. Utterances have contents which count as their meanings. Semantics is a branch of linguistics which studies meaning from various theoretical positions. This branch of linguistics is not necessarily the study of acceptable theoretical positions on what the meanings of words and sentences are, or should be, but it is the study of the various perspectives for the interpretation of meaning. It is a growing field of language study. Semantic enquiry is interdisciplinary; it incorporates logic, mathematics and philosophy (but particularly logic). The interdisciplinary and complex nature of semantics makes it reasonable to focus on the normative aspects of contemporary semantics for an introductory presentation of the subject in scholarship. The four major topics in semantics (which the scope of this paper will not satisfactorily explain) include: (i) the nature of meaning; (ii) some of the properties of the conceptual system underlying meaning; (iii) the computation of syntactic structure to the interpretation of sentences; and (iv) the role of non-grammatical factors in the understanding of utterances (cf. O' Grady and Archibald 2004:174).

\section{Pragma-Lexico-Semantic Corpora of Nigerian English}

Acheoah and Adeoye (2014:109-110) submit that the semantic corpora of Nigerian English include local coinages that conform to the morphological processes of Standard British English (SBE), and such elements result from new experiences, and linguistic creativity. Examples include:

- half-current - (instead of SBE "low current" or "low power supply");

- cover-cloth - (instead of SBE "pajamas", "dressing gown" or "sheet");

- cushion(-ed) chair - meaning "chair with cushions" - (instead of SBE "armchair");

- bushmeat - also a loan translation ( for SBE "game");

- bukateria - a wayside eating place; from the Hausa bukka and the Yoruba buka - (instead of SBE "cafeteria");

- beer parlour- (instead of SBE "public house" or "pub");

- chewing-stick - a piece of wood, which can be softened by biting it; meant for tooth cleaning (no SBE form);

- corper- (no SBE alternative; but some NE varieties use "corps members", i.e., a tertiary institution graduate who is enlisted to serve the country for a period of 12 months);

- hot (drinks) - (instead of SBE “spirits", i.e., varieties of strong alcoholic drinks such as whisky, brandy, gin and schnapps); 
- Send-forth - The SBE equivalent for this word is "send-off". However, many Nigerians choose to use "send forth".

Other examples of coinages are "storey-building", "working-class", "working-place", walking-stick, etc. In coining words for needed cultural meaning, creativity is demonstrated by Nigerian speakers of English as they produce words for concepts that are not present in SBE. Of course, some of such words are present in the English culture, but are too remote for easy comprehension, and some are modified because of the negative connotations they are perceived to have.

Acheoah (2013) submits that the following expressions are products of Nigerian existential experiences:

- "Ex-service man" (a former soldier only);

- "Dealer" (one who sells automobile);

- "V-boot" (a particular type of car irrespective of the fact that other brands have v-shaped boots);

- "Macleans" (all brands of toothpastes);

- “419” (fraud or fraudsters);

- "mama-put" (an unbefitting place where cooked food is sold);

- "I am coming" (I am going but will be back soon);

- "I am strong" (I am sick/not well);

- "Cream" (pomade only);

- "The trader charges buyers" (The trader makes buyers pay so much/the trader sells at high cost).

\section{DEFENDING NigERIAN ENGLISH CORPORA}

The preceding section of this paper shows what obtain as corpora of Nigerian English. In this section, I present the following points to justify the pragma-lexico-semantic data of Nigerian English:

\subsection{Message-Driven Potentials}

In the use of the English Language, the Nigerian speaker's linguistic choices are informed by illocutionary goals irrespective of the norms of English. Lawal's Communicative Model Theory explains that in effective discourse, the medium of communication is inevitably determined by the message as the speaker or writer hinges on various stylistic devises including pragmatically informed lexical deviants. It is unfortunate that some scholars regard NE deviant forms as "substandard English" or "taboos". I strongly hold the view that the shared knowledge, context and participants' relationship which direct NE utterances are despised by NE critics. When a Nigerian parent tells his child, "When you get to school today, greet your uncle", he acknowledges the normative use of the word "uncle" (a brother to one's child/children), but deviates from exploring such a denotative meaning, to exploring a connotative meaning that the pupil (the child) understands. Of course, in the Nigerian context, primary school pupils, staff and parents have shared knowledge that "uncle" and "aunty" are nomenclatures for male and female teachers respectively. However, male and female teachers of secondary and tertiary institutions in Nigeria are not referred to as "uncles" and "aunties" respectively. The mystery of social system cannot be relegated to the background. Social system is indeed, a natural, region-determined phenomenon. Re-inventing the meaning of the word "charge" (used as a verb), a Nigerian may tell another Nigerian, "Avoid that trader's shop because he charges buyers". Thus, the speaker uses the verb "charge" to mean "making buyers pay so much", rather than using it to mean "making buyers pay for what they buy" (of course, traders have to charge buyers). The pragmatic purpose of using the word in the Nigerian context is to achieve desired perlocutionary effects (see Austin 1962 for tips on locutionary, illocutionary and perlocutionary acts) on the hearer. If participants of discourse cannot select linguistic structures to suit their communicative intentions, of what use is human communications? One does not expect a non-Nigerian to use the verb "charge" as the Nigerian user uses it, in a speech community where the pragma-lexico-semantic existentialism for such usage does not exist.

\subsection{Inexhaustible Nature of Meaning}

Meaning is not exhaustible. Thomas Carlyle, cited in O' Grady and Archibald (ibid.174), opines that "in every object there is inexhaustible meaning." Therefore, the use of English in a decolonized Nigerian society should 
transcend linguistic conventions (norms) or constants. Regional and idiosyncratic use should not only be accommodated, but should also be recognized. There are instances of idiosyncratic use of English by native speakers. Scholars use the phrase "mistakes and popular etymology" to refer to individualistic errors that become acceptable in the everyday-use of a particular language. It is therefore logical to recognize pragma-lexico-semantic Nigerianisms within the ambit of world Englishes (WE).

Ayodabo and Acheoah (2013) submit that the standardization of Nigerianisms in Nigerian English and the resultant nativization is a panacea to the age-long language question in Nigeria where arguments for, or against English have been influences by centripetal and centrifugal attitudes. While communicating in English, linguistic choices of Nigerians are germane to cultural constraints and the pragmatics of varied situations. Indeed, the nativization of English is a pre-requisite for maximizing the dividends of English as a global asset. Although Nigerians use English contrary to form, their Nigerian decoders do not find it difficult to locate the referents (what Allan 1986 refers to as "the-world-spoken-of") in their utterances. Every Nigerian speaker of English has illocutionary goal(s) which language is used or modified to achieve. Geoimplicatures cut across various spheres of the Nigerian daily life. The elements subtly creep into Nigerian English, and gain acceptability over time. They are not intelligible to the native speakers of English, who are bereaved of the socio-cultural contexts which produce such elements.

\subsection{Size of Speakers}

Apart from the samples listed in this study as English expressions that are Nigerian, others abound that a vast majority of Nigerians use in both written and spoken communications. Indeed, the mass media has promoted the pragmatic, lexical and semantic credentials of NE by inducing people across class or status to use Nigerianized forms in ways germane to contexts.

"Vitality" is one of the attributes for classifying language. It has to do with the functional potency of a language and the size of its speakers. Given the growing number of speakers of Nigeria English, the variety should be accommodated, promoted and recognized internationally ${ }^{3}$.

\subsection{National Development}

There has been much "shout-outs" against the dominance of the colonial language (English) in Nigeria. While some scholars suggest that a majority Nigerian language should replace English in formal contexts, there are those who view the proposal as something not feasible, given the fact that indigenous languages have divisive potentials and cannot cope with the challenges of globalization. However, I do not think an alien language is an indispensible instrument of national development. Japan's breakthrough in electronic and automobile industry might have been hindered if a foreign language were to be the medium of instruction in formal education in the country. If an indigenous Nigerian language cannot be recognized as an instrument of development, then the indigenized English can be an intermediate alternative. Given its social or mobilization functions, Nigerian English is instrumental to the country's development; the pragmatic, lexical and semantic potentials of Nigerian English are veritable resources for development. The recent outbreak of Ebola virus in Nigeria has informed various conferences by seasoned academics across disciplines, towards finding a lasting solution to the epidemic. Subsequently, papers were written on the roles of language in creating awareness. The government realized that ignorance on the part of the populace could lead to the widespread of the deadly disease. Productive media efforts towards giving the populace the muchneeded awareness will be predicated by good use of Nigerianisms. Thus, slang, Nigerian Pidgin and re-invented English expressions (Nigerianized British or American English expressions) will be facilitators of the awareness campaign. Nigerianisms may be used as verbal accompaniments in cartoons or in jingles as they appeal to the Nigerian psyche during such campaigns.

There is no doubt that a speech community's language goes a long way in achieving needed development for the people. Poor implementation of language policies has been the problem with Nigeria. The government of Nigeria, in collaboration with linguists, should be sincere and purposeful towards her language development policies. Mabogunje (ibid., p.7) states "that the key to development lies in men's minds, in the institutions in which their thinking finds expressions..." The thinking of many Nigerians about the common forceful and violent attitude of retired soldiers gave birth to the expression "ex-service man". To register pragmatic competence in Nigerian English, a Nigerian speaker ensures that this expression is used only when the context or situation is germane.

\subsection{Linguistic Nationalism}

Nigeria should be determined to locate, promote and uphold whatever counts as NE corpora ${ }^{4}$. It is sociolinguistic injustice to relegate English expressions that do not conform to the norms of British or American English. Adeniran 
points out that what was formally regarded as Nigerian Pidgin English, is now referred to as Nigerian Pidgin. Oppressive tendencies towards Nigerian English should be abated through linguistic nationalism. American English was promoted and so, rose to the crescendo through the conscious, lexicographic efforts of Noah Webster. Today, the variety is a threat to the predating British English on an embarrassing, explosive continuum.

Figure 1 illustrates NE indigenization (re-invention of British or American English in the Nigerian multilingual milieu) process and its scope:

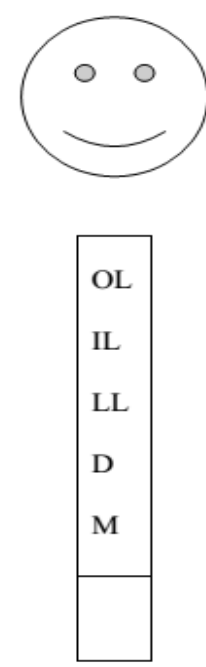

Fig1. Scope and Process of Indigenization

Key:

OL: (Operative Language) IL: (Indigenized Language)

LL: (Linguistic Level) D: (Domain) M: (Meaning)

Figure 1 above presents English as the Operative Language which is re-invented by Nigerians to produce the Nigerian English corpora at different levels of linguistic analysis, including morphology, pragmatics and semantics. Nigerianisms are produced from different facets of human endeavour. Such facets (domains) include politics, commerce, health, entertainment industry, sports, religion, education, etc. Each Nigerianism (Geoimplicature) has a meaning or meanings which are essentially the states-of-affairs they address ${ }^{5}$. Therefore, Nigerian English corpora do not exist in a vacuum as they are products of Nigerians' existential experiences.

\section{DISCUSSION AND CONCLUSION}

The study establishes that within the ambit of World Englishes (WE), there is Nigerian English. Mbisike (2007) contends that the form of every language is affected by social, economic, political and cultural factors. It is logical for Nigerian English corpora to be discrete from British English corpora since Britain and Nigeria have different norms and values. NE continues to be a veritable candidate in regional English discourse as it is germane to the socio-cultural nuances of its users.

Passed from one generation to another, language preserves the socio-cultural identity of its speakers to a large extent. This idea of "continuity" is vital in the explanation of Nigerian English data. Nigerianisms depict identity, social emancipation and originality. Besides, they may not be class-based; the youth, adults, literates and illiterates may explore same Nigerian pragma-lexico-semantic corpora in communicative events.

A research of this sort, presupposes a clear understanding of the gamut of Nigerian English data as the linguistic data of a particular "speech community". A speech community refers to a community of speakers whose experiences and behavioral patterns are evident and conveyed in one language. Investigating the linguistics of the Nigerian speech community also presupposes a clear understanding of the term "society", which refers to people living together in a community. The social groups which constitute the structure of society include race, nation, speech community, state and ethnic group. The dimensions the English language takes in the communications of Nigerians are therefore not incidental. Indeed, Fowler (1981:10) opines that "linguistic structure is not arbitrary, but is motivated and determined by the functions it performs." Leech (1983) asserts that he "did not attempt cross-cultural 
comparison of communicative behaviour, but acknowledges that research into the area would be fascinating." He observes that the transfer of the norms of one community into another may well lead to pragmatic failure. Language is a tool for social interaction hence, context phenomena cannot be excluded from it.

\section{Notes}

- At various stages after colonialism, the language changes due to social dynamics in Nigeria; socially realistic phenomena inform "nativized" varieties, and this trend operates as a continuum.

- Conventions connected with social situations affect communicative interactions.

- Nigerian English deserves codification. Fishman (1972:18-22) suggests four attributes which determine language attitudes: standardization (codification and acceptability of the norms of a given language as defined by a given speech community); autonomy (the unique attributes of the language); historicity (the language's ancestral origin): and vitality (the potency of the language in communication).

- Adeniran, cited in Ayodabo (2013:219) submits that "language determination is a most important activity in a multilingual society."

- I use the term "states-of-affairs" as a paraphrase of Searle's direction-of-fit (cf. Searle 1969) and Allan's worldspoken-of (Allan ibid.).

\section{REFERENCES}

[1] Acheoah, John Emike (2011). "A Pragmatic Analysis of Ayi Kwei Armah's The Beautyful Ones Are Not Yet Born and Ola Rotimi's Hope of the Living Dead." PhD diss., Ahmadu Bello University.

[2] (2013). "Saying x: The Pragmatics of a Nigerian Context." Studies in Literature and Language Vol. 6(3) (2013):39 - 44.

[3] Acheoah, John Emike, \& Adeoye, A. O. (2014). "The Semantics of Nigerian Languages." in Issues in Language and Linguistics: Perspectives from Nigeria Vol. I. eds. Ayodabo J. O. \& Butari N. Kaduna: Language Group of Nigeria.109-110.

[4] Adegbija, Efurusibina (1999). The English Language and Literature in English: An Introductory Handbook. Ilorin: Haytee Press.

[5] Akindele, F., \& Adegbite, W. (1999). The Sociology and Politics of English in Nigeria: An Introduction. Ile Ife. Obafemi Awolowo University Press Limited.

[6] Allan, Keith (1986). Linguistic Meaning Vols. I and II. London: Routledge and Kegan Paul.

[7] Austin, John (1962). How to Do Things with Words Cambridge: Harvard University Press.

[8] Ayodabo, Joel (2012). "Nigerian English in the Context of Globalization" (paper presented at the departmental seminar series, Department of English, Ajayi Crowther University, Oyo, March 23rd, 2012).

[9] (2014). Linguistic and Sociolinguistic Situation in Nigeria. Ilorin: Haytee Press. p. 219.

[10] Ayodabo, Joel \& Acheoah, John Emike (2013). "Nigerian English in a Decolonized State: Prospects and Constraints." International Journal of Arts and Humanities, 2(2):48-52.

[11] Banjo, Ayo \& Yang, P., (1982). "On Editing a Second Language Dictionary: The Proposed Dictionary of West African English.” English Worldwide, 3(2) (1982):4.

[12] Encyclopedia Americana (1994).Vol.22. International Ed. (New York: Americana Group Ltd. p.514.

[13] Fishman, J. A. (1972). The Sociology of Language: An Interdisciplinary Social Science Approach to Language in Society (Cambridge, Mass: Newbury House Publishers.

[14] Fowler, R. (1981). Essays on Style and Language ed. Fowler R. London: Routhledge \& Kegan Paul. p.10.

[15] Lawal, A. (2012). Aspects of a Stylistic Theory and the Implications for Practical Criticism ed. Lawal A. Ilorin: Applied Linguistics Study Group (ALSG), University of Ilorin.

[16] Leech, Geofrey (1983). Principles of Pragmatics. London: Longman.

[17] Lucas, J. M. (2002). "Content Packaging for Mass Communication Transactions in Nigeria: Challenges and Prospects." in Work in Progress no. 13. eds. Aliyu et (Zaria: Department of English and Literary Studies, Ahmadu Bello University. p. 33.

[18] Mbisike, R. C. (2007). "On Standardizing Nigerian English: An Argument."In Sociolinguistics in the Nigerian Context ed. Adeyanju D. Ile-Ife: Obafemi Awolowo University Press Ltd.

[19] O’ Grady, W. \& Archibald, J. (2004). Contemporary Linguistic Analysis: An Introduction eds. O’ Grady W. \& Archibald J.

[20] Canada: Pearson Education.:p.174.

[21] Searle, John (1969). Speech Acts: An Essay in the Philosophy of Language (New York. Cambridge University Press.

[22] Wierzbicka, Ann (1991). Cross-cultural Pragmatics (New York. Monten de Gruyter). 